\title{
Grid Voltage Stability Enhancement Using Photovoltaic Based Static Synchronous Compensator
}

\author{
${ }^{1}$ Arun Bhaskar Mayilvaganan, \\ ${ }^{2}$ Subhransu Sekhar Dash and ${ }^{1}$ Venkatesh Venkataramanan \\ ${ }^{1}$ Department of EEE, Velammal Engineering College Chennai, India \\ ${ }^{2}$ Department of EEE, SRM University, Kattankulathur, Chennai, India
}

Received 2012-08-01, Revised 2012-08-29; Accepted 2013-04-17

\begin{abstract}
Today, we are mostly dependent on non renewable energy that have been and will continue to be a major cause of pollution and other environmental degradation. Because of these problems and our dwindling supply of petroleum, finding sustainable alternatives is becoming increasingly urgent. Perhaps, the greatest challenge is in devising a sustainable future, which relies on integration and control of renewable energy sources in grid distributed generation. This study presents the usage of utilizing Photovoltaic (PV) Solar Farm (SF) during idle conditions as Static Synchronous Compensator (STATCOM), to regulate the point of common coupling voltage when the wind farm supply the power to the grid. The proposed control will enable increased connections of WECS to the grid. MATLAB/Simulink based simulation results are presented for validation of the system. The PV-STATCOM increase the stability of the grid with interconnected wind farm system without any use of additional compensator.

Keywords: Photovoltaic (PV), Solar Farm (SF), Voltage-Source Inverters (VSI), Doubly-Fed Induction Generator (DFIG), Distributed Generation (DG), Wind Energy Conversion System (WECS), Static Synchronous Compensator (STATCOM), Voltage Regulation
\end{abstract}

\section{INTRODUCTION}

Today, we are mostly dependent on non renewable energy that have been and will continue to be a major cause of pollution and other environmental degradation. Because of these problems and our dwindling supply of petroleum, finding sustainable alternatives is becoming increasingly urgent. Perhaps, the greatest challenge is in devising a sustainable future, which relies on integration and control of renewable energy sources in grid distributed generation.

Generation of power locally at distribution voltage level by using non-conventional (or) renewable energy sources like, solar photo voltaic cells, wind power, biogas and fuel cell is known as Distributed Generation (DG).

The following technical, economical and environmental benefits have led to the gradual development and integration of DG systems:
- Due to rapid load growth, the need for augmentation of conventional generation brings about a continuous depletion of fossil fuel reserves

- Reduction of environmental pollution and global warming acts as a key factor in preferring renewable resources over fossil fuel

- DG systems provide better scope for setting up cogeneration, tri regeneration for utilising the waste heat for industrial/domestic/commercial applications. This increases the overall energy efficiency of the plant and also reduces pollution to the environment

- Due to lower energy density and dependence on geographical conditions of a region, renewableenergy systems are generally modular units of small capacity. These are geographically widespread and usually located close to loads Corresponding Author: Arun Bhaskar Mayilvaganan, Department of EEE, Velammal Engineering College Chennai, India 
- Stand alone and grid connected operation of renewable energy systems help in generation augmentation, thereby improving overall power quality and reliability

With the development of distributed generation systems, the renewable electricity from PV sources became a resource of energy in great demand. The current control scheme is mainly used in PV inverter applications for real power and reactive power control schemes. The emergence of wind generation is the leading source of renewable energy in the power industry, Wind farms totalling hundreds, even thousands, of MW are now being considered. DFIG is the main type of wind generation currently in use (the other is conventional induction generators) due to their variable speed operation, four-quadrant active and reactive power capability, low-converter cost and reduced power losses.

\subsection{System Modelling}

\subsubsection{DG System Modelling}

Figure 1 shows the single-line diagram of the wind energy system with battery storage and VSI. A WF modelled as a fully controlled converter-inverterbased doubly-fed induction generator and a PV SF modelled as a voltage-source inverter.

There are a number of grid connected PV models available in literature.

A new islanding detection behavior of a gridconnected photovoltaic system in the presence and absence of the feed-forward control scheme is also proposed in literature (Yazdani and Dash, 2009).

A stepwise analytical methodology starting at the solar resource and culminating in the value of the PV system in terms of avoided costs is provided. The methodology includes processing of the solar irradiance; identification of the PV system's configuration and operational features; identification of real-time system controls in the presence of $\mathrm{PV}$ generation; security assessment in the presence of PV and production costing and capacity expansion analysis with PV (Chowdhury, 1992).

\subsection{PV Solar Farm as Battery Charger}

A PV Model is developed using basic circuit equations of the Photovoltaic (PV) solar cells including the effects of solar irradiation and temperature changes in MATLAB environment (Altas and Sharaf, 2007).

A typical PV solar farm is basically inactive during night time and the bidirectional inverter used to deliver the PV DC power as three-phase AC power to the grid, remains unutilized as well. Figure 2 shows the possible operational modes of the solar farm. The point at which the solar farm is connected to the grid is called the Point of Common Coupling (PCC). In Fig. 2, $\mathrm{V}_{\mathrm{S}}$ and $\mathrm{i}_{\mathrm{S}}$ represents the voltage and current at the secondary of the distribution transformer; $\mathrm{V}_{\mathrm{PCC}}$ and $\mathrm{V}_{\mathrm{L}}$ denote voltages at PCC and load terminal respectively; and $i_{\mathrm{PV}}$ is the current delivered by the PV solar panels ac current drawn/delivered by the solar farm inverter and the DC current flowing through the storage battery are represented by $i_{S F}$ and $i_{B a t t}$, respectively. Here a storage battery is connected on DC side of the solar farm inverter. Switch "S1" in Fig. 2 is utilized to disconnect the PV solar panels especially during night-time and to charge the storage batteries from the main grid (Varma et al., 2009).

\subsection{Doubly Fed Induction Generator}

DFIG is an abbreviation for Double Fed Induction Generator, a generating principle widely used in wind turbines. It is based on an induction generator with a multiphase wound rotor and a multiphase slip ring assembly with brushes for access to the rotor windings. It is possible to avoid the multiphase slip ring assembly but there are problems with efficiency, cost and size. A better alternative is a brushless wound-rotor doubly-fed electric machine.

The principle of the DFIG is that rotor windings are connected to the grid via slip rings and back-toback voltage source converter that controls both the rotor and the grid currents. Thus rotor frequency can freely differ from the grid frequency $(50$ or $60 \mathrm{~Hz}$ ).

By using the converter to control the rotor currents, it is possible to adjust the active and reactive power fed to the grid from the stator independently of the generator's turning speed. The control principle used is either the two-axis current vector control or Direct Torque Control (DTC). DTC has turned out to have better stability than current vector control especially when high reactive currents are required from the generator (Babu and Mohanty, 2010).

The stator of the wound rotor induction machine is connected to the low voltage balanced three-phase grid and the rotor side is fed via the back-to-back PWMvoltage-source inverters with a common DC link. Grid sides converter controls the power flow between the DC bus and the AC side and allows the system to be operated in sub-synchronous and super synchronous speed. The proper rotor excitation is provided by the machine side power converter and also it provides active and reactive power control on stator and rotor sides respectively by employing vector control. 


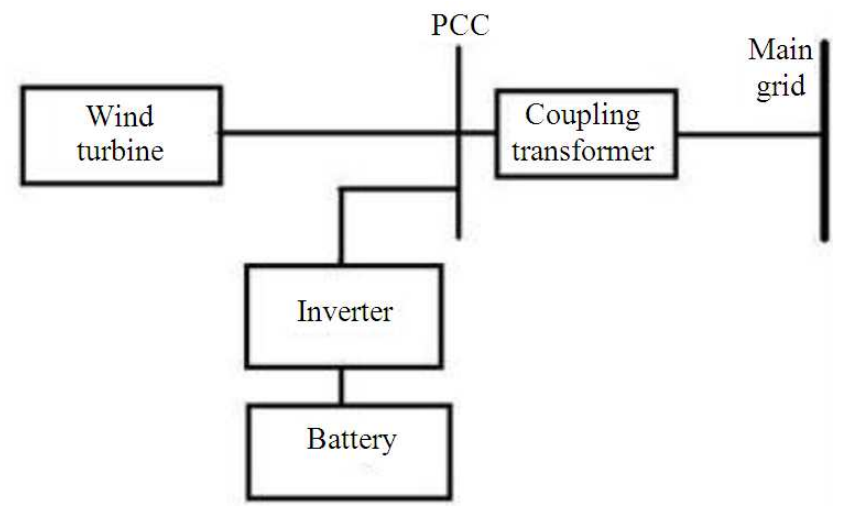

Fig. 1. Wind energy system with battery storage and VSI

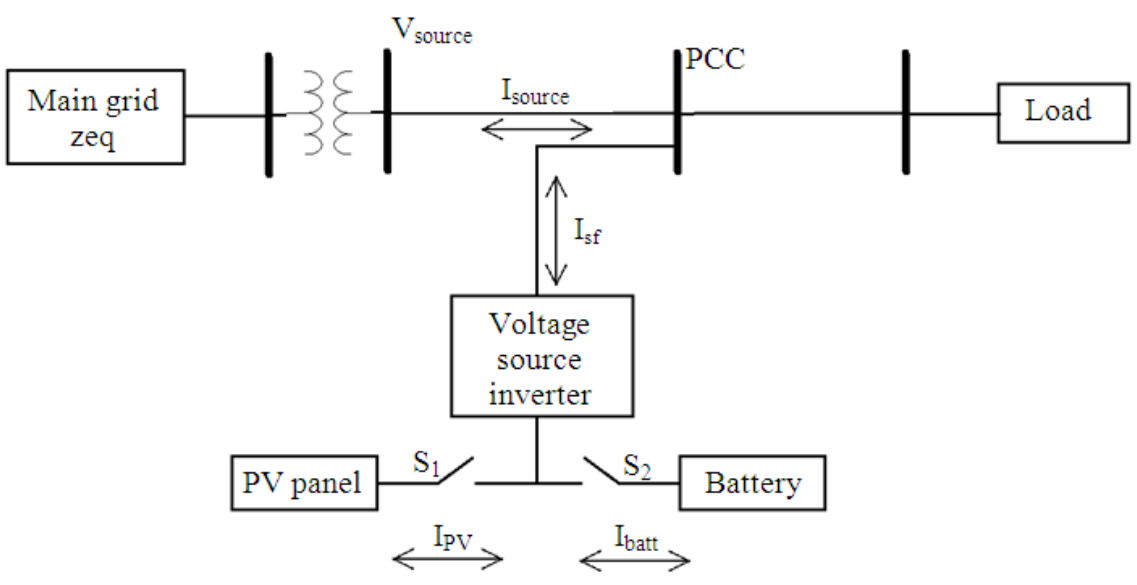

Fig. 2. Solar farm inverter as the battery charger system configuration

The crowbar will short-circuit the rotor windings through a small resistance when excessive currents or voltages are detected. In order to be able to continue the operation as quickly as possible an active crowbar has to be used. The active crowbar can remove the rotor short in a controlled way and thus the rotor side converter can be started only after $20-60 \mathrm{~ms}$ from the start of the grid disturbance. Thus it is possible to generate reactive current to the grid during the rest of the voltage dip and in this way help the grid to recover from the fault.

The AC/DC/AC converter is divided into two components: the rotor-side converter and the gridside converter. The Voltage-Sourced Converters thatluse forced-commutated power electronic devices (IGBTs) to synthesize an AC voltage from a DC voltage source. A capacitor connected on the DC side acts as the DC voltage source. A coupling inductor $\mathrm{Lf}$ is used to connect grid side converter to the grid. The three-phase rotor winding is connected to rotor side converter by slip rings and brushes and the three phase stator winding is directly connected to the grid. The power captured by the wind turbine is converted into electrical power by the induction generator and it is transmitted to the grid by the stator and the rotor windings.

\subsection{STATCOM}

Recently the Voltage Source Inverter (VSI) based Static VAR compensators have been used for reactive power control (Hingorani and Gyugyi, 2000). These compensators are known as Advanced Static VAR Compensator (ASVC) or Static Synchronous Compensator (STATCOM) shown in Fig. 3. 


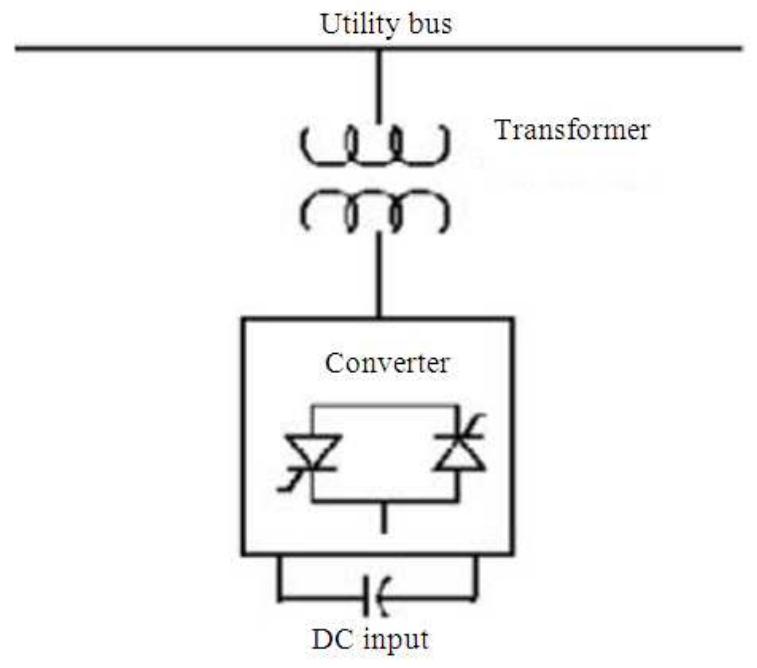

Fig. 3. Line diagram of STATCOM

The Static Synchronous Compensator (STATCOM) is a shunt connected reactive compensation equipment which is capable of generating and/or absorbing reactive power whose output can be varied so as to maintain control of specific parameters of the electric power system. The STATCOM provides operating characteristics similar to a rotating synchronous compensator without the mechanical inertia, due to the STATCOM employ solid state power switching devices it provides rapid controllability of the three phase voltages, both in magnitude and phase angle. The STATCOM basically consists of a step-down transformer with a leakage reactance, a three-phase GTO or IGBT Voltage Source Inverter (VSI) and a DC capacitor.

\subsection{SF Inverter Control}

Figure 4 shows the block diagram of the control scheme used to achieve the proposed concept. The controller is composed of two Proportional-Integral (PI) based voltage-regulation loops. One loop regulates the PCC voltage, while the other maintains the dc-bus voltage across SF inverter capacitor at a constant level.

The PCC voltage is regulated by providing leading or lagging reactive power during bus voltage drop and rise, respectively. A Phase-Locked Loop (PLL) based control approach is used to maintain synchronization (Hingorani and Gyugyi, 2000) with PCC voltage. A hysteresis current controller is utilized to perform switching of inverter switches. To facilitate the reactive power exchange, the dc-side capacitor of SF is controlled in self-supporting mode and thus, eliminates the need of an external dc source (such as battery) (Khadkikar et al., 2009).

\subsection{Simulation Study and Results}

To validate the concept presented in the study, MATLAB/ SIMULINK based simulation study is carried out. A Test system consists of integration of both wind energy system and PV Array system.

Wind turbines using a Doubly-Fed Induction Generator (DFIG) consist of a wound rotor induction generator and an AC/DC/AC IGBT-based PWM converter modeled by voltage sources. The stator winding is connected directly to the $50 \mathrm{~Hz}$ grid while the rotor is fed at variable frequency through the $\mathrm{AC} / \mathrm{DC} / \mathrm{AC}$ converter. The DFIG technology allows extracting maximum energy from the wind for low wind speeds by optimizing the turbine speed, while minimizing mechanical stresses on the turbine during gusts of wind.

The respective grid voltage, Grid current, rotor voltage, rotor current and stator voltage of the turbine are shown in Fig. 5.

PV array is made to act as DC capacitor for the STATCOM designed and is interfaced to the system at the $25 \mathrm{kv}$ bus as in Fig. 6 .

The simulation results are given in Fig. 7-9.

Case1: Under normal condition the voltage and current profile in the $25 \mathrm{kv}$ bus is as shown in Fig. 7a here after an initial fluctuation for about $0.2 \mathrm{sec}$ the voltages and currents profile is well within the $\pm 5 \%$ pu value criteria. The reason for the fluctuation is due to change over of speed from $8-14 \mathrm{~m} \mathrm{sec}^{-1}$. The simulation is conducted for duration of $2 \mathrm{sec}$. Also the zoomed view of the voltages and currents is shown in Fig. $\mathbf{7 b}$.

Case2: When the system in acting under normal condition single phase short circuit fault is set on the "phase A" line at the $25 \mathrm{kv}$ bus at the instant of $0.8 \mathrm{sec}$. The voltage decreases and current increases after the instant at 0.8 as shown in the Fig. 8 and propagates till the complete cycle of the simulation.

Case3: In this case the fault is implemented at $25 \mathrm{kv}$ bus at about $0.8 \mathrm{sec}$ and is allowed to propagate. At $1 \mathrm{sec}$ $\mathrm{PV}$ array STATCOM is brought into action and after 1.2 sec system is compensated and system is restored to normal condition after $1.2 \mathrm{sec}$ as shown in Fig. 9. 
Arun Bhaskar Mayilvaganan et al. / Journal of Computer Science 9 (3): 299-307, 2013
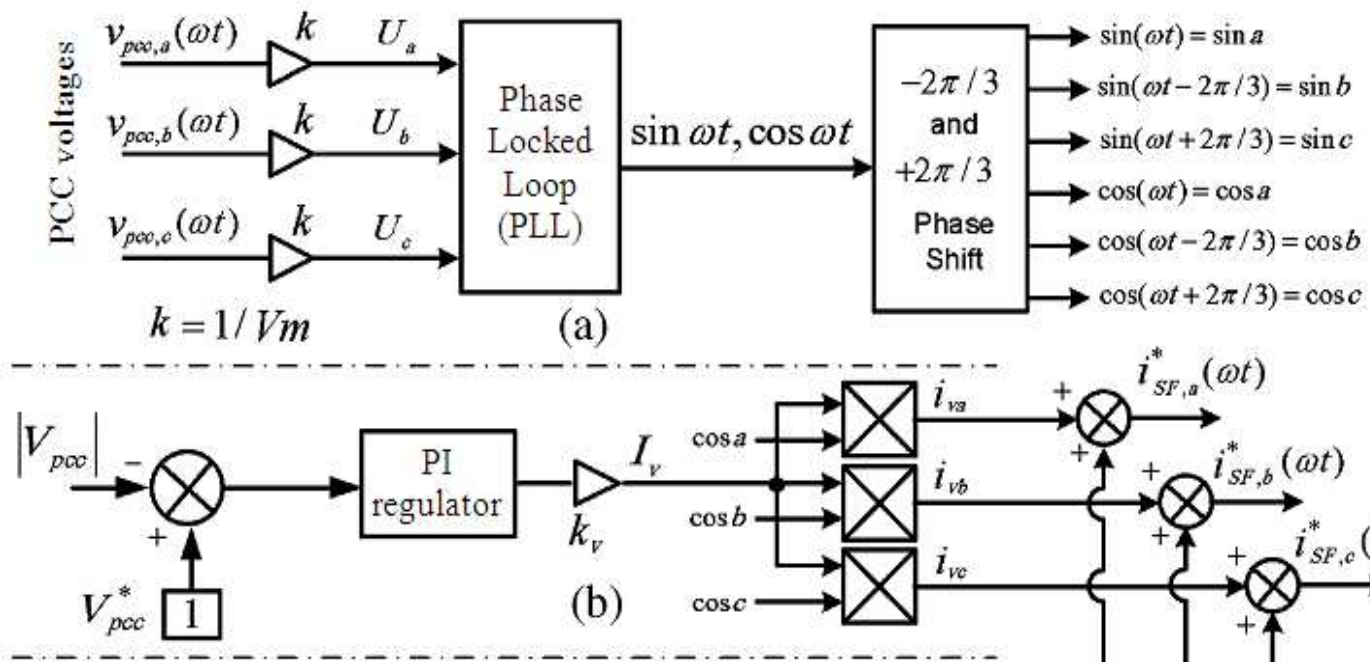

(a)
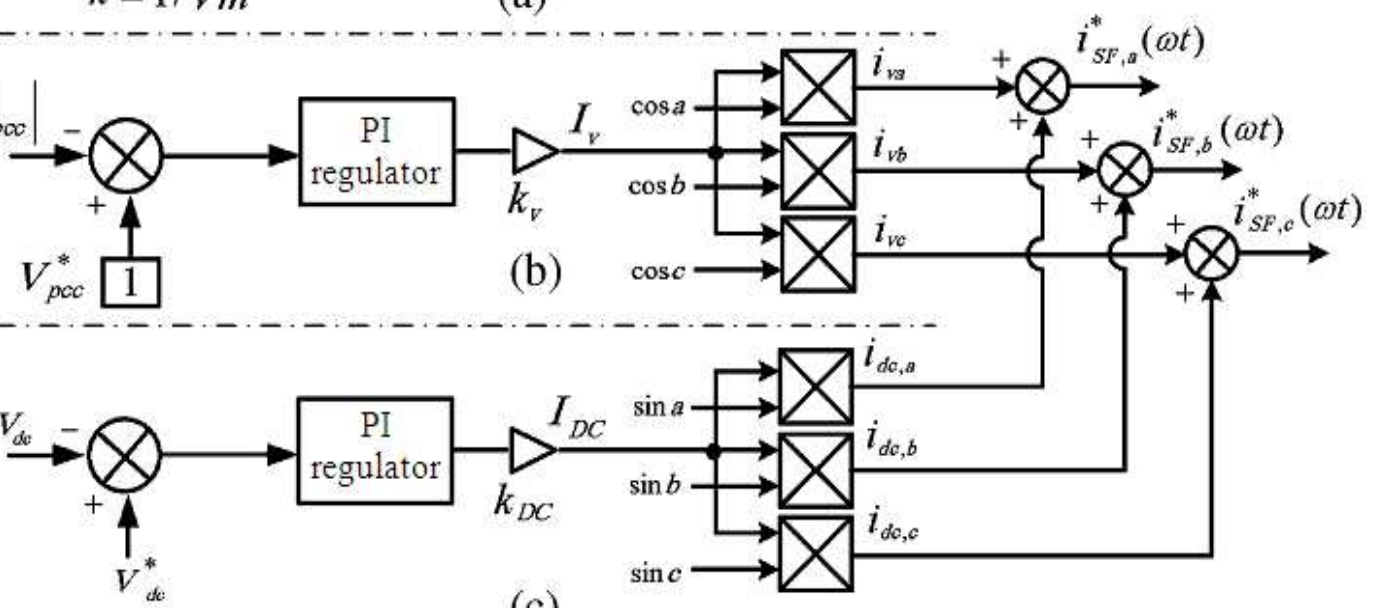

(c)

Fig. 4. SF as STATCOM Controller diagrams. (a)Synchronization (b) PCC voltage regulation loop. (c) DC bus voltage regulation loop

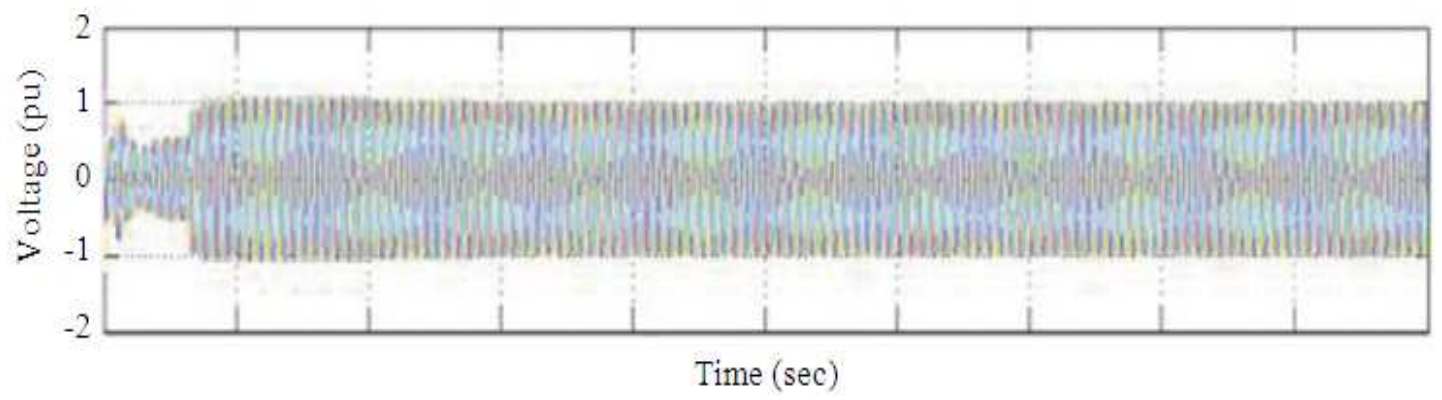

(a)

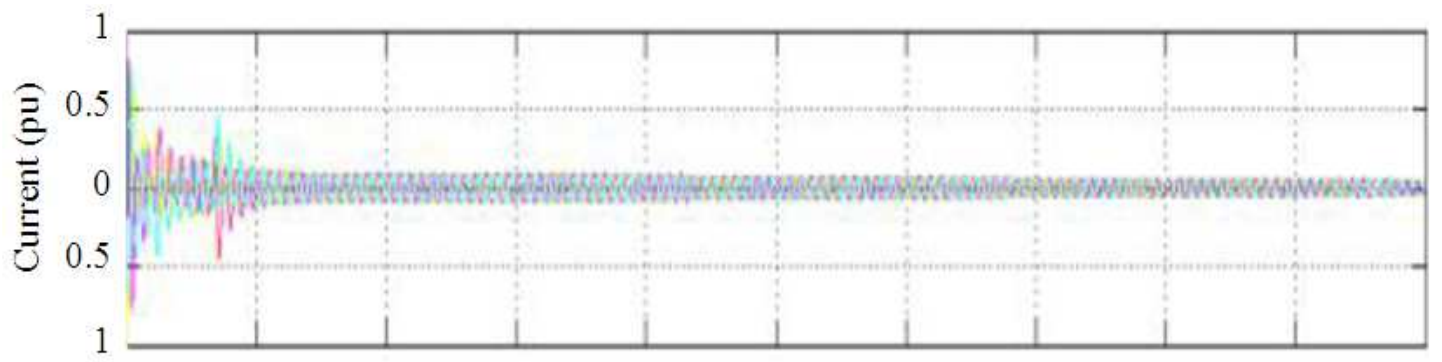

Time (sec)

(b) 


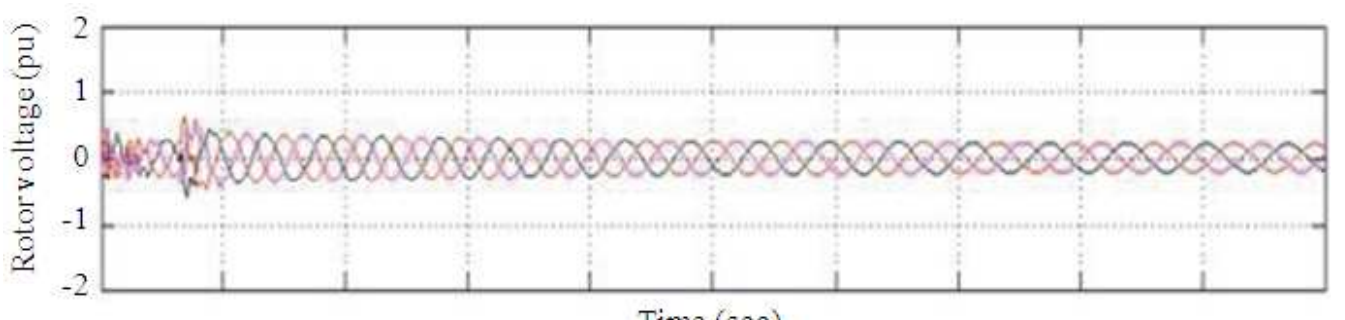

(c)

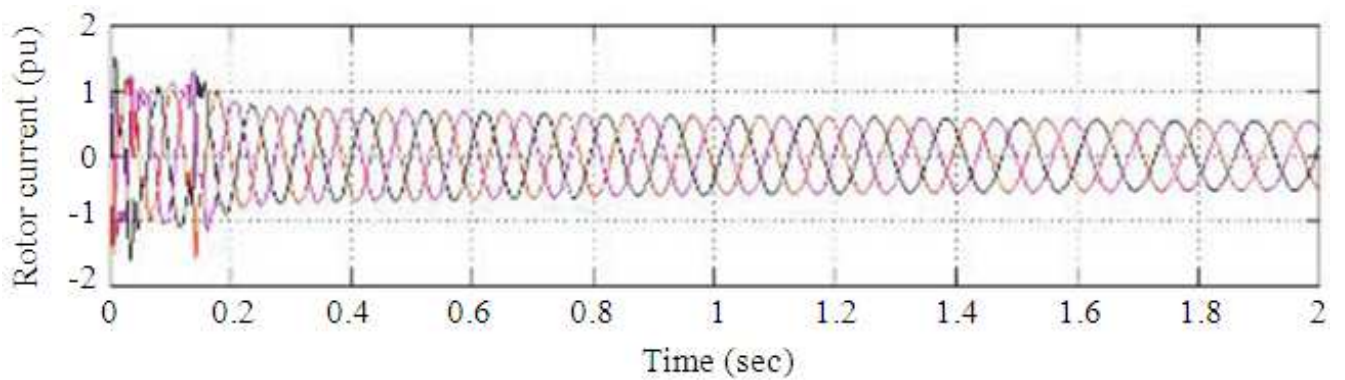

(d)

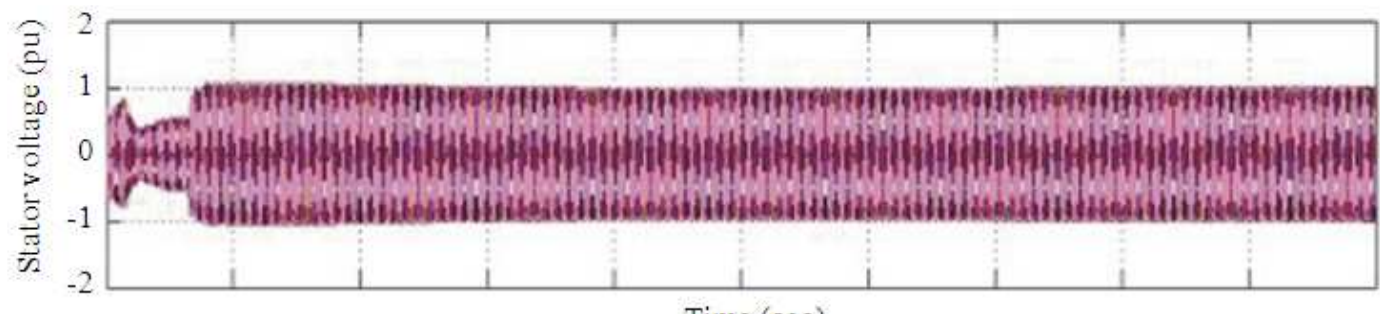

Time $(\mathrm{sec})$

(e)

Fig. 5. (a) Grid voltage, (b) current, (c) rotor voltage, (d) current, (e) stator voltage of the turbine

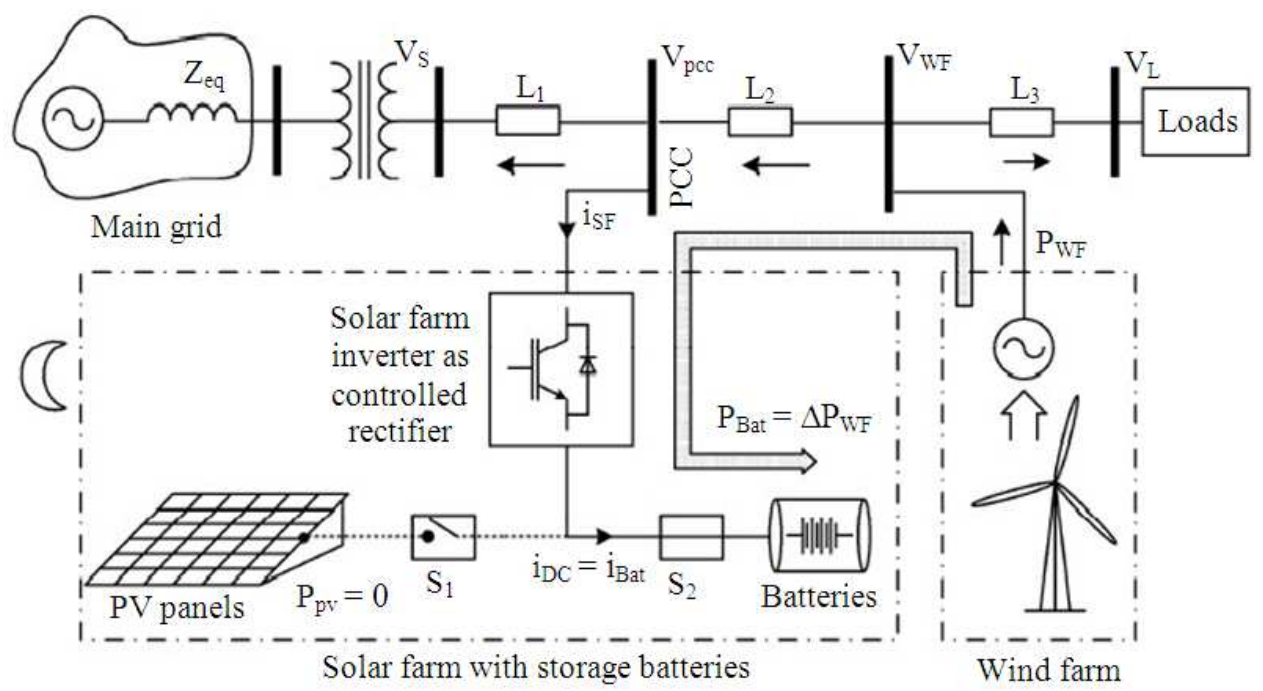

Fig. 6. Block diagram representation of proposed utilization of solar farm during night time 

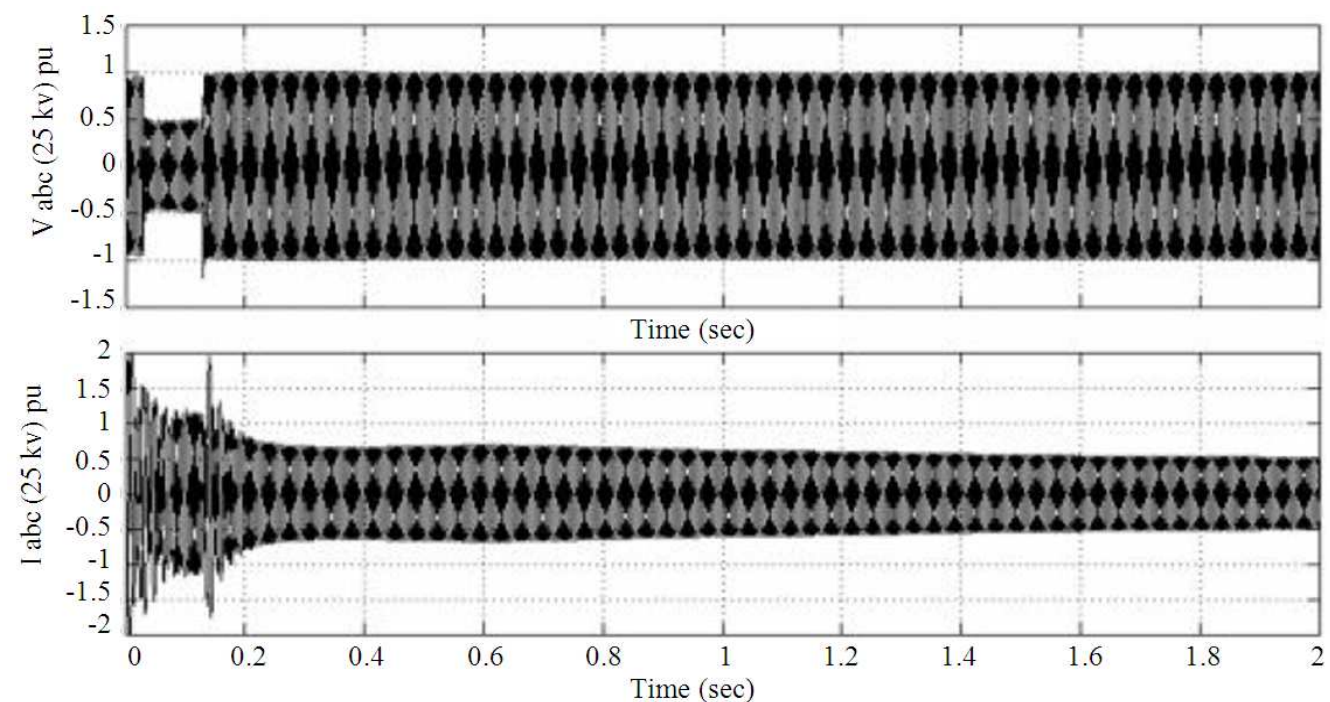

(a)
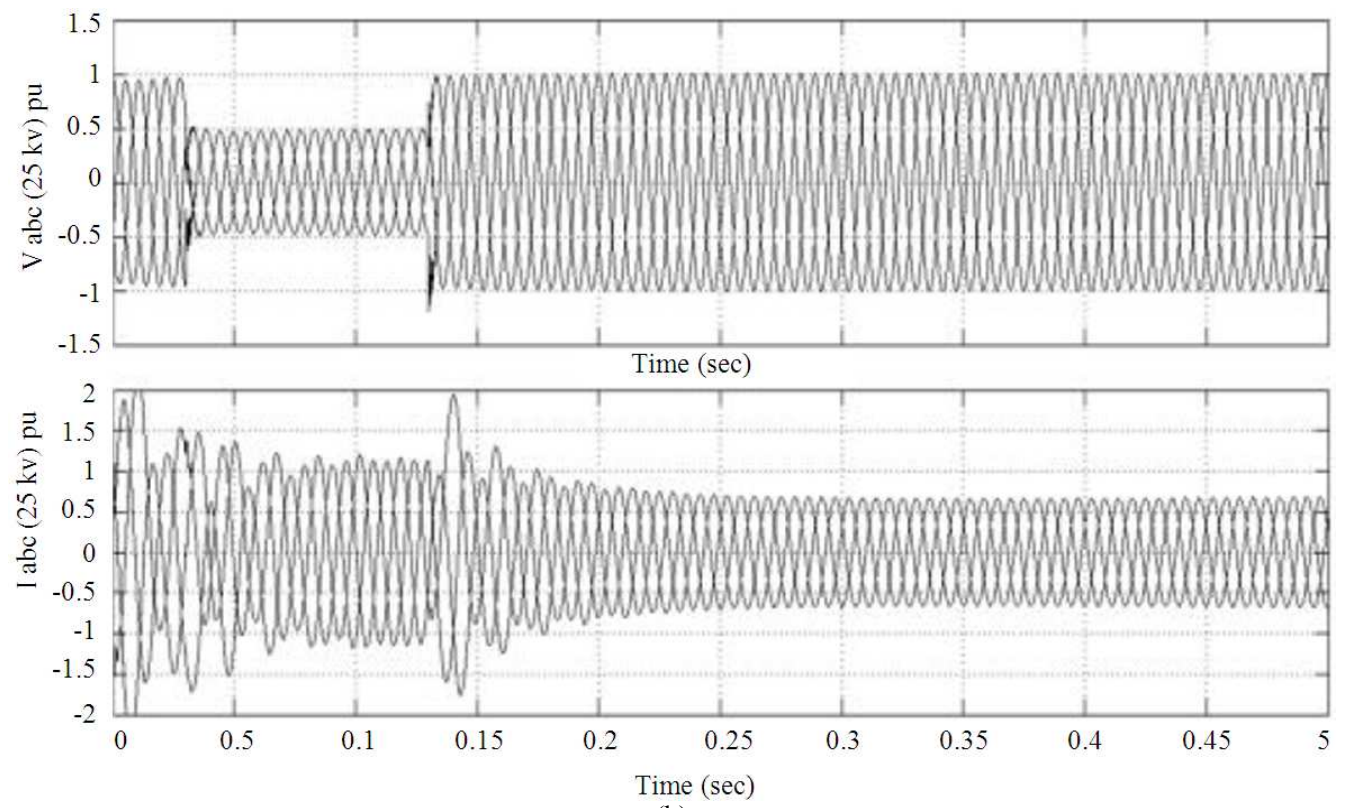

(b)

Fig. 7. Voltage and current at $25 \mathrm{kv}$ bus under normal condition

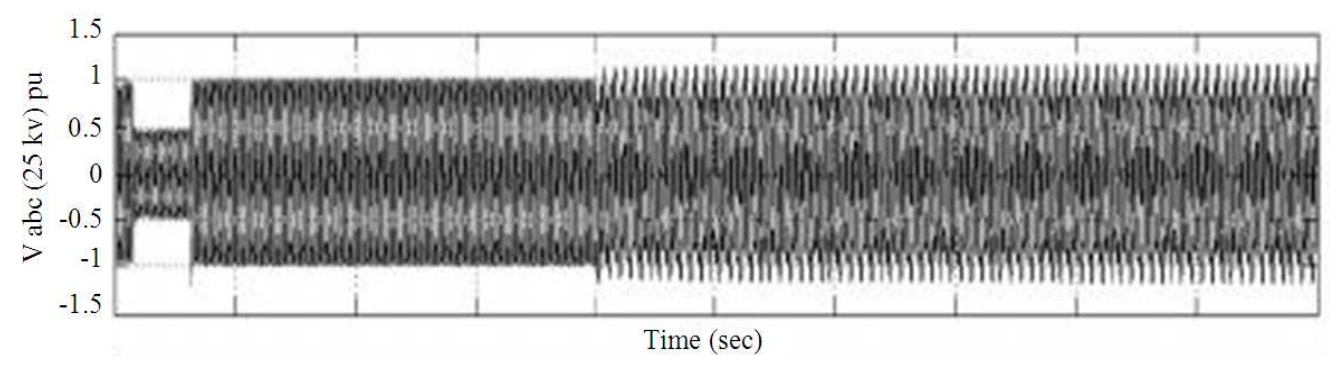




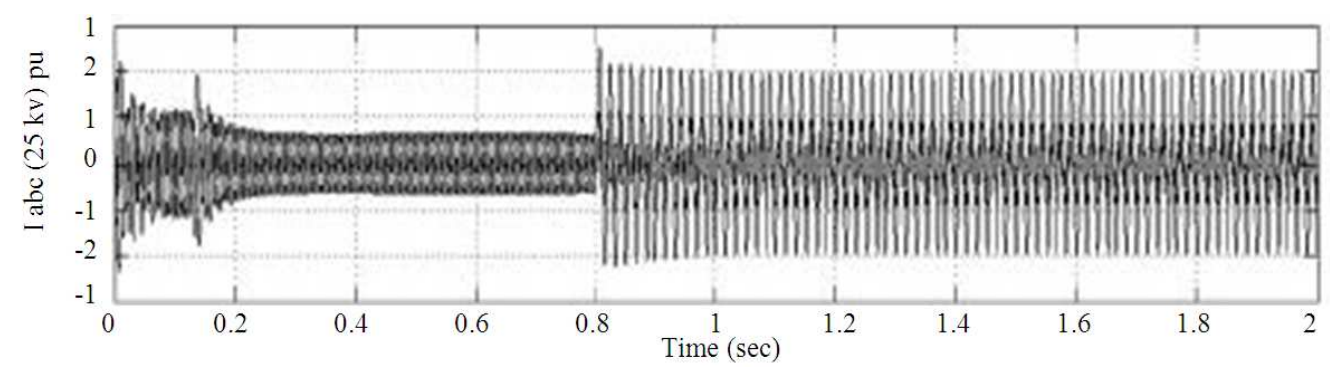

Fig. 8. Voltages and current profile at the $25 \mathrm{KV}$ bus after fault

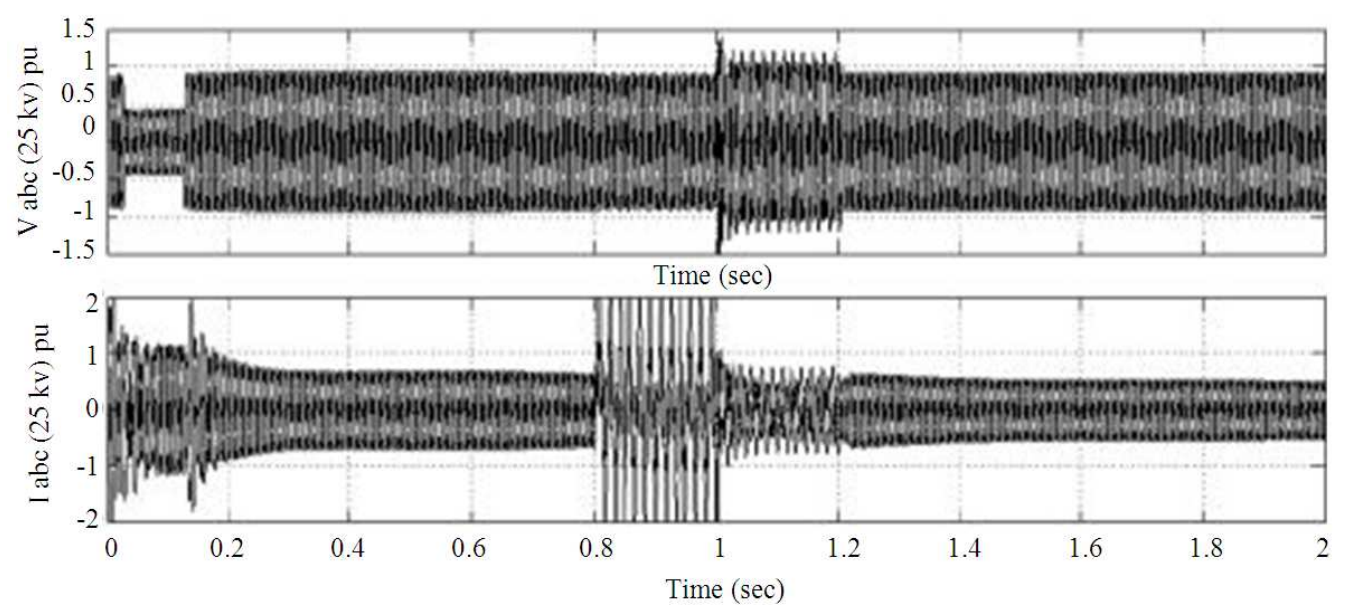

Fig. 9. Voltage and current profile at $25 \mathrm{KV}$ bus after STATCOM action

\section{CONCLUSION}

A novel concept of optimal utilization of a PV SF as a STATCOM has been proposed and validated through MATLAB/SIMULINK simulation. The proposed strategy of PV SF control will facilitate integration of more wind plants in the system without needing additional voltage-regulating devices. This study has discussed about the problem on grid connection of distributed generators at the point of common coupling during requirement. It deals with the approach of utilizing the distributed generators itself for providing the remedies to the encountered problem, thereby reducing the cost, size of the system and also the losses. On this account the simulation of the wind energy conversion system and also the photo voltaic array solar energy simulation have been done and the respective outputs have been obtained. PV array based STATCOM design was implemented and interfaced with the energy system. A single phase to ground fault was conducted on the transmission line and STATCOM was acted upon the system to provide the compensation required. The system was restored to normal condition. Hence the required simulations were executed in SIMULINK software and required outputs were obtained.

\section{REFERENCES}

Altas, I.H. and A.M. Sharaf, 2007. A Photovoltaic array simulation model for MATLAB-simulink GUI environment. Proceedings of the International Conference on Clean Electrical Power, May 21-23, IEEE Xplore Press, Capri, pp: 341-345. DOI: 10.1109/ICCEP.2007.384234

Babu, B.C. and K.B. Mohanty, 2010. Doubly-fed induction generator for variable speed wind energy conversion systems-modeling and simulation. Int. J. Comput. Electr. Eng., 2: 141-147.

Chowdhury, B.H., 1992. Optimizing the integration of photovoltaic systems with electric utilities. IEEE Trans. Energy Conver., 7: 72-78. DOI: $10.1109 / 60.124544$ 
Hingorani, N.G. and L. Gyugyi, 2000. Understanding FACTS: Concepts and Technology of Flexible AC Transmission Systems. 1st Edn., Wiley, New York, ISBN-10: 0780334558, pp: 432.

Khadkikar, V., R.K. Varma and R. Seethapathy, 2009. Grid voltage regulation utilizing storage batteries in PV solar-wind plant based distributed generation system. Proceedings of the IEEE Electrical Power and Energy Conference, Oct. 22-23, IEEE Xplore Press, Montreal, QC., pp: 1-6. DOI: 10.1109/EPEC.2009.5420966
Varma, R.K., V. Khadkikar and R. Seethapathy, 2009. Nighttime application of PV solar farm as STATCOM to regulate grid voltage. IEEE Trans. Energy Conver., 24: 983-985. DOI: 10.1109/TEC.2009.2031814

Yazdani, A. and P.P. Dash, 2009. A control methodology and characterization of dynamics for a Photovoltaic (PV) system interfaced with a distribution network. IEEE Trans. Power Delivery, 24: 1538-1551. DOI: 10.1109/TPWRD.2009.2016632 